\title{
AKTSAR
}

ISSN 2622-5255 (online)

Volume 1 Nomor 1, Juni 2018, Halaman 57-71

ISSN 2622-2345 (cetak)

\section{Realitas Bansos Hibah: Lika Liku Pilu Auditor Internal \\ (Studi Kasus Provinsi Indraprasta)}

\author{
Anggun Anita Sari \\ Universitas Airlangga \\ anjunmoyish@gmail.com
}

\begin{abstract}
This study aims to describe how the role of the government internal auditors carries out examination tasks, especially in the implementation of social assistance and grants. This study finds that the informant's efforts are actually quite persistent in conducting the audit. However, there are many factors that influence the process of inspection such as the limited human resources, the existence of legislative interest and the character of the receiver itself. Based on understanding of informant roles, there are three audit acts, the first, avoidance if audit was very high risk. Second, justification that emphasizes a neat accountability report rather than audit implementation. Third, safekeeping that give solution and ensure that the missused funds re-deposited to the treasury funds.
\end{abstract}

Keywords: Social Assistance; Grants; Roles; Government Internal Auditor 


\section{ABSTRAK}

Penelitian ini bertujuan untuk mendeskripsikan bagaimana realitas peran auditor internal pemerintah daerah dalam menjalankan tugas pemeriksaan khususnya dalam pelaksanaan bantuan sosial dan hibah. Metode penelitian yang digunakan adalah studi kasus. Penelitian ini menemukan bahwa upaya informan sebenarnya cukup gigih dalam melakukan audit. Namun banyak faktor yang mempengaruhi jalannya pemeriksaan bansos hibah, yaitu, keterbatasan SDM, adanya kepentingan legislatif dan faktor penerima bansos hibah itu sendiri. Berdasarkan peran yang dipahami auditor internal, terdapat tiga bentuk pelaksanaan audit, yaitu pertama, penghindaran jika kasus yang akan diperiksa memiliki risiko yang sangat tinggi. Kedua, pembenaran yaitu mementingkan laporan pertanggungjawaban yang rapi daripada pelaksanaan di lapangan atau form over substance. Ketiga, pengamanan yaitu memberikan solusi dan memastikan bahwa dana yang disalahgunakan kembali disetor ke kas negara.

Kata kunci: Bantuan Sosial; Hibah; Peran; Auditor Internal Pemerintah

\section{PENDAHULUAN}

"Lhoh mbah..pundi kambing bantuan ingkang diparingi niko..." "Waduh nak..pun kulo sade..niki dados ali-ali..." (ilustrasi informan Jarwo)

Kasus Bansos Hibah mendominasi kasus yang ditangani Polda Indraprasta selama Tahun 2015. Tercatat dari 91 kasus korupsi 40 diantaranya merupakan kasus bansos hibah. Modus operandi kasus korupsi Bansos Hibah yang ditangani beragam antara lain seperti pemalsuan data penerima yang tidak sesuai, perubahan Rencana Anggaran dan Biaya (RAB) secara sepihak hingga pendistribusian yang tidak tepat sasaran. (Antara.com, 12 Desember 2015). Ikhtisar Hasil Pemeriksaan BPK pada Tahun 2010 pun menemukan sejumlah penyimpangan Bansos di 19 Provinsi yang nilainya sangat fantastis mencapai Rp 765 Miliar. Tiga besar dalam temuan BPK tersebut adalah Provinsi Indraprasta. Bukti lain yaitu adanya pemotongan atas hibah riil di Indraprasta pada Tahun 2012 dan 2013 antara 10-50 persen untuk macammacam alasan yang tidak masuk akal seperti untuk biaya administrasi, biaya pengurusan dan commitment fee untuk anggota DPR (lensaindonesia.com, 8 Juni 2015).

Pemerintah Daerah dalam melakukan Pengelolaan Keuangan haruslah efektif, efisien, ekonomis, transparan, responsif dan memiliki akuntabilitas publik yang tinggi (Mardiasmo, 2002). Policy yang dibuat pemerintah muaranya adalah kemakmuran, sehingga setiap Rp 1,- penggunaan uang APBN/APBD yang salah satunya bersumber dari pajak rakyat, harus membawa kenaikan kesejahteraan sebesar Rp 1,- pula (Ketua BPK-RI Harry Azar Azis 13 Mei 2016). Ekonomi Indraprasta menurut Badan Pusat Statistik (BPS) terus mengalami percepatan dan bahkan pada Triwulan III Tahun 2014 tumbuh 6,02\%, lebih cepat dibanding nasional yang tumbuh sebesar 5,11\%. Namun demikian pada 4 April 2016 yang lalu, secara Nasional Provinsi ini menempati urutan kedua untuk kasus balita gizi buruk sebagaimana ditulis wartawan Harian Surya 
Lintartika (2015). Fenomena gizi buruk ini 35\% disebabkan oleh kemiskinan. Terbersit sebuah tanya, apakah gempuran bansos hibah selama ini belum mampu mengurangi kemiskinan yang ada sehingga masih ditemukan gizi buruk di Indraprasta. Jika merujuk pernyataan Ketua BPK-RI diatas, peningkatan APBD diikuti pula dengan peningkatan kesejahteraan dan bukanlah sebaliknya. Apalagi, postur anggaran bansos hibah tiap tahunnya lebih dari 25\% dari keseluruhan APBD nya (Data APBD 2014 sd 2017).

Pemahaman peran yang harus dijalankan oleh tiap individu auditor dalam menginterpretasikan peran yang diterima khususnya dalam pelaksanaan Bansos Hibah sedikit banyak membawa dampak bagi akuntabilitas bansos hibah. Pengalaman tiap individu auditor internal ini akan diteliti untuk mendapat penjelasan bahwa auditor satu dengan yang lain memiliki pemaknaan yang berbeda karena pengalaman masing-masing dengan situasi yang tidak seragam dan muaranya akan memberi pemahaman akan peran yang dijalankan.

Roussy (2013, p. 567) telah melakukan penelitian tentang peran auditor internal pemerintah di Quebec. Hasil menunjukkan bahwa auditor internal melakukan dua peran kunci. Pertama sebagai peran pelindung yang dibagi lagi menjadi dua peran yaitu perisai pelindung dan penjaga rahasia. Kedua sebagai peran pembantu yang juga terbagi kembali menjadi dua peran yaitu pendukung kinerja dan pemandu dalam organisasi. Analisis juga menunjukkan bahwa auditor internal mengembangkan konsepsi tentang kemerdekaan 'Abu-abu' untuk melakukan peran mereka. Auditor internal menganggap bahwa peran utama adalah melayani manajer puncak dan organisasi dan mereka harus memprioritaskan manajer puncak dengan mengorbankan anggota komite audit. Kajian lain tentang peran auditor internal dilakukan oleh Chempaka (2015). Hasil penelitiannya yaitu peran pembimbing/konsultan telah sesuai dengan harapan dari peraturan akan tetapi terdapat peran pelindung yang tidak diharapkan dalam peraturan, melainkan terbentuk karena hal alami seperti pengaruh struktur organisasi, frekuensi pertemuan dengan para pengirim peran, dll. Serta masih kurangnya kompetensi dan independensi auditor internal di Inspektorat Kabupaten B menjadi salah satu alasan mengapa masih saja terjadi penyalahgunaan anggaran pemerintah di daerah.

Santoso (2016) juga melakukan penelitian terhadap auditor internal di Inspektorat yaitu pada Kabupaten M. Diperoleh pemahaman tentang berbagai makna Efektivitas Peran APIP. Peran diterjemahkan oleh auditor sebagai "pembina" yang terbagi lagi menjadi fungsi penindakan dan pencegahan. Efektivitas yang kurang maksimal ditengarai karena kurangnya SDM secara jumlah dan kompetensi, dukungan anggaran dan faktor individu. Selain itu dukungan atasan juga menjadi faktor kendala secara struktural. Gamar dan Djamhuri (2014, p. 120) melakukan sebuah penelitian yang bertujuan memahami peran auditor internal pemerintah daerah dalam upaya meminimalisir fraud pada lingkungan pemerintah Kabupaten $S$. Melalui sembilan orang pengawas/auditor sebagai informan kunci, ditemukan bahwa auditor internal pemerintah daerah adalah "Dokter" fraud. Namun demikian, "Dokter" fraud belum dapat melaksanakan perannya secara maksimal, karena minimnya kompetensi auditor internal, dan belum adanya komitmen dari manajemen puncak serta unsur-unsur terkait dalam pemerintahan di daerah. 
Shariha (2014, p. 27) juga melakukan penelitian mengenai peran biro audit dalam memberantas korupsi di Libya. Anggota State Audit Bureau (SAB) Libya merasakan meski ada peraturan yang memberi mereka "berkuasa" untuk memberantas korupsi, mereka tidak memiliki peran sebanyak yang mereka rasakan dalam melakukan audit negara. Penyebabnya antara lain dari peraturan yang tidak mencukupi, pelatihan dan pendidikan untuk aparatur teknis untuk melakukan audit yang kurang. Hal ini menyebabkan kegagalan untuk mencocokkan keuangan dan administrasi, keputusan hukum, dan keputusan eksekutif. Kondisi ini Ditambah dengan kompetensi yang tidak mencukupi Anggota SAB Libya. Biro audit Anggota tidak memiliki pengalaman yang luas dan kapasitas teknis untuk menjalankan fungsinya. Namun hubungan antara anggota Biro Audit dan pemerintah Institusi dicirikan oleh kerjasama dan semangat tanggung jawab. Penelitian ini pun bertujuan dapat membentuk sebuah analogi peran yang dilaksanakan, yang dimaknai secara tersendiri oleh auditor Inspektorat Indraprasta dalam fraud yang lebih spesifik yaitu pada pelaksanaan Bansos Hibah.

Menurut Akai dan Sakata (2002, p. 52) pertumbuhan ekonomi dapat dicapai melalui pelaksanaan desentralisasi fiskal yaitu dimana Kepala Daerah memiliki wewenang untuk mengelola keuangan yang diperoleh dari transfer pusat. Dan menurut penelitian Adil dan Anwar (2015), desentralisasi fiskal berpengaruh pada pertumbuhan ekonomi. Namun demikian desentralisasi fiskal ini pula yang membawa angin segar dalam korupsi di Indonesia. Hal ini mencoreng semangat otonomi daerah yang sejatinya merupakan hak dan kewajiban Kepala Daerah untuk mengatur sendiri rumah tangganya karena lebih memahami secara teknis dan menciptakan kemandirian, berbalik menjadi transfer virus korupsi di daerah. Modus penyelewengan yang banyak dilakukan adalah dengan memanfaatkan sektor belanja daerah dalam bentuk bansos hibah (Syafingi, 2014), Bansos Hibah digunakan petahana untuk melakukan sosialisasi/kampanye (Syafingi, 2014) (Widada, 2015) dan dana bansos hibah sering disalah gunakan oleh pemerintah daerah, dengan modus membuat LSM Fiktif dan lain lain (Heriani, 2012).

Sesuai dengan Peraturan Menteri Dalam Negeri Nomor 32 Tahun 2011, Hibah adalah pemberian uang/barang atau jasa dari pemerintah daerah kepada pemerintah atau pemerintah daerah lainnya, perusahaan daerah, masyarakat dan organisasi kemasyarakatan, yang secara spesifik telah ditetapkan peruntukannya, bersifat tidak wajib dan tidak mengikat, serta tidak secara terus menerus yang bertujuan untuk menunjang penyelenggaraan urusan pemerintah daerah. Sedangkan Bansos adalah pemberian bantuan berupa uang/barang dari pemerintah daerah kepada individu, keluarga, kelompok dan/atau masyarakat yang sifatnya tidak secara terus menerus dan selektif yang bertujuan untuk melindungi dari kemungkinan terjadinya resiko sosial.

Dalam Buletin Teknis SAP Nomor 10, yang dimaksud dengan Belanja Bantuan Sosial berkelanjutan yaitu bantuan yang diberikan secara terus menerus untuk mempertahankan taraf kesejahteraan sosial dan upaya untuk mengembangkan kemandirian. Contoh yang bersifat sementara: Pemerintah memberikan bantuan terhadap orang cacat, namun setelah orang tersebut dapat mandiri, belanja bantuan sosial tersebut dihentikan. Contoh yang bersifat berkelanjutan: Pemerintah memberikan bantuan terhadap orang cacat yang tidak pernah dapat mandiri, belanja 
bantuan sosial tersebut dapat diberikan secara berkelanjutan. Masih dalam Buletin Teknis SAP, disebutkan dalam Nomor 13 bahwa dalam rangka pengendalian penggunaan hibah, penerima hibah wajib mempertanggungjawabkan penggunaan dana yang diterima dengan menyusun dan menyampaikan pertanggungjawaban penerimaan hibah dalam bentuk laporan kepada pemberi hibah secara tepat waktu sesuai dengan yang diperjanjikan dalam naskah perjanjian hibah. Belanja ini di beberapa daerah tidak efektif dan banyak penyimpangan dalam pelaksanaannya (Achyani, 2014), (Eftriani, 2014).

Penelitian terkait bantuan sosial sebelumnya antara lain dilakukan pada aspek akuntabilitas penggunaan dana bansos seperti dilakukan Mandasari, Darmawan, dan Atmadja (2015, p. 9) dengan hasil penelitian bahwa penerima bansos hibah memaknai akuntabilitas penggunaan bansos sesuai dengan konteks spiritual yang dianutnya. Sementara Rahmawati (2016) meneliti proses penetapan dan pengelolaan dana bansos hibah di Surakarta dan menemukan ketidaktertiban dalam proses pertanggungjawabannya. Penelitian yang membahas Sistem Pengendalian Internal Pemerintah dalam bansos hibah (Delli, 2014) di Aceh Tengah memberikan hasil bahwa kelemahan dalam SPIP membawa dampak resiko dalam belanja bantuan sosial. Sementara penelitian Evaluasi Audit Bansos Hibah oleh Widati (2016) pada Inspektorat Kabupaten Kulonprogo menunjukkan bahwa proses audit investigatif belum efektif karena belum memiliki pedoman.

Achyani (2014) meneliti analisis efekivitas pelaksanaan belanja bantuan sosial pada Pemerintah Kabupaten Pontianak dan menemukan inefektif belanja bantuan sosial. Pengungkapan Belanja Bansos Hibah pada Laporan Keuangan telah diteliti oleh Darmastuti dan Setyaningrum (2012) dan penelitian tentang Perumusan Bansos Hibah oleh Eftriani (2014) di Pemerintah Provinsi Bangka Belitung adalah pada proses perumusannya. Sedangkan Manossoh (2015) meneliti penyebab fraud pada pengelolaan belanja bansos hibah Pemerintah Kota Manado dan menunjukkan hasil bahwa faktor struktur birokrasi, sumber daya, transparansi akuntabilitas dan responsibilitas menjadi penyebab fraud. Sedangkan penelitian ini berfokus pada bagaimana pelaksanaan peran masing-masing auditor pada saat menjalankan pemeriksaan Bansos Hibah.

\section{METODE PENELITIAN}

Penelitian ini menggunakan studi kasus dalam menemukan peran auditor internal dalam menjalankan tugas memeriksa bansos hibah. Studi kasus dalam penelitian ini adalah mengembangkan analisis mendalam dengan pokok masalah "bagaimana" pemahaman peran auditor internal dalam kasus tunggal yang dipilih yaitu bansos hibah dengan pendekatan/ metode penelitian kualitatif. Riset studi kasus mencakup studi tentang suatu kasus dalam kehidupan nyata, dalam konteks atau setting kontemporer (Yin, 2013).

Data penelitian diperoleh melalui observasi dan wawancara mendalam. Observasi dilakukan peneliti secara partisipatif dengan bergabung pada sebuah tim pemeriksaan yang sedang menangani kasus pada penerima hibah yaitu sebuah lembaga pemerintah. Dalam melakukan observasi, peneliti ikut membantu jalannya pemeriksaan dengan membantu melakukan input dokumen dalam rekapitulasi pertanggungjawaban. Sedangkan wawancara mendalam dilakukan kepada 6 orang 
informan. Yang terdiri dari 4 orang auditor internal dan 2 orang pejabat struktural. Informan yang dipilih adalah auditor yang telah mengabdi selama lebih dari sepuluh tahun, sehingga informasi yang disampaikan merupakan pengalaman yang benarbenar dipahami dari waktu ke waktu. Sementara pejabat struktural yang dilibatkan dalam penelitian ini adalah penanggungjawab dalam Tim yang diikuti peneliti dalam observasi, serta pejabat yang sering melakukan tindak lanjut hasil pemeriksaan.

Bansos dan hibah merupakan tema yang memerlukan kemampuan wawancara yang tricky dan pandai mengorek lebih dalam, agar informasi yang didapat tidaklah normatif belaka. Penelitian ini menggunakan pseudonym yang berarti di dalam penelitian tidak dicantumkan nama asli informan melainkan nama samaran. Hal ini dimaksudkan untuk menjaga kerahasiaan identitas informan agar informan tidak keberatan untuk memberikan informasi penting selama penelitian berlangsung. Situs penelitian dipilih pada Provinsi Indraprasta karena peran auditor dalam menjalankan tugas lainnya antara lain :

1. Reviu atas Laporan Keuangan Pemerintah Daerah,

2. Pengawas penyelenggaraan Pemerintah Daerah,

3. Pembinaan, assurance dan reviu atas kinerja organisasi,

dipandang telah cukup berhasil karena prestasi Provinsi ini dengan bukti capaian yang diperoleh yaitu Opini WTP, Parasamya Purnakarya Nugraha dan Nilai A pada SAKIP-nya. Namun demikian, catatan yang masih menjadi ganjalan adalah pelaksanaan Bansos Hibah yang menjadi catatan BPK tiap tahunnya. Hal inilah yang menjadi motivasi penelitian mengapa peran auditor internal belum nampak keberhasilannya dalam pemeriksaan Bansos Hibah.

\section{HASIL DAN PEMBAHASAN}

\section{Pemeriksaan pada Penerima Hibah Kelompok Masyarakat (Pokmas).}

Sering dalam pemeriksaan yang berlangsung, auditor menemui kendala klasik yaitu pemimpin pokmas penerima hibah tidak mau ditemui. Jika menemui hal seperti ini pastilah terjadi "sesuatu" dalam pengelolaan hibah yang diterimanya.

"Waktu meriksa terkesan gegeran ya sering. Contohnya kemarin aja, mbahas satu forum gitu kan di bawah naungan pondok besar ya, karena mbulet, orangnya mbulet, nggak ngaku-ngaku, akhirnya kita kan gini prosedurnya, karena kita nggak punya kemampuan untuk memaksa. Inspektorat kan bukan aparat penegak hukum, ya kubilang gini, ya udah klo nggak mau ngaku saya disini, sampe ngaku mau 2 hari ya dua hari, akhirnya keturutan 2 hari. Dari pagi sampai pagi lagi. Pagi ini datang, bukan pagi sih, jam 11, aku pulang itu bukan besok jam 11 tapi besoknya lagi, jam 4 isuk. Ning kono.ya makan ya pergi makan, mbalik maneh. Yo tak tunggoni wong e... Pimpinan, nggak mau nemuin, artinya proses itu nggak bisa dijalankan ketika kita tdk bisa menemui yg bertanggungjawab. Ya sudah, daripada wira-wiri mending tak tunggoni. Diklaim ya akhirnya ya bayar." (Informan Narto).

Kewenangan auditor memang sebatas melakukan pengawasan. Di satu sisi tidak dapat memaksa seseorang mengakui kesalahan sebagaimana layaknya aparat penegak hukum. Namun demikian harus mampu menemukan fraud dan menjaga agar bantuan yang diberikan tidak diselewengkan. Diceritakan dengan ekspresi agak 
kesal oleh Informan Bapak Narto pada wawancara di siang yang panas, bahwa dia harus menginap di sebuah lokasi penerima hibah, karena dia yakin setelah pemeriksaan yang dilakukan terdapat dana yang tidak dapat dipertanggungjawabkan. Pemimpin pokmas yang awalnya enggan menemui, enggan mengakui temuan dan enggan mengembalikan uang yang tidak digunakan sesuai proposal yang dia tulis, akhirnya luluh berkat tim auditor yang gigih nginep (menginap) selama dua malam di tempat penerima hibah.

Diselingi menyeruput coke dingin, Pak Narto kembali mengisahkan pengalaman lain memeriksa sebuah sekolah kejuruan

"Pengalaman lagi, ada SMK. Berita acara itu selese tanpa di tandatangani oleh penerima, kepala sekolahnya dulu. Sekarang mereka tidak setuju. Ya aku bilang, nggak apa-apa kalau bapak tidak setuju. Tapi yang jelas saya sudah kesini, sudah melakukan pemeriksaan, hasilnya ini, ya inilah laporan saya. Ada kelebihan 20 jutaan. Kalau bapak nggak mau kembalikan ya nggak apa-apa, saya nggak minta untuk dikembalikan, saya nggak untung kok. Ini kan untuk keamanan dan untuk kebaikan penerima. Besoknya, saya telpon. Ngobrol-ngobrol lagi by phone, Karena udah ditempat lain to.. Kan kalau hibah itu, paling datang kesitu sekali thok to.. Habis gitu pergi lagi, pergi lagi gitu. Telpon, maunya itu kalau bisa dikurangi. Ora iso tho, angel lho. Terlalu mencolok gitu kan. Entah seminggu lagi atau 4-5 hari lagi gitu dia kembalikan. Udah, dgn marah2 gitu. Udah pak, ya sudah saya cuman butuh bukti setor, difoto, diemail. Kan nggak mbalik maneh. kan sudah pergi lagi ke tempat lain, aku yo wegah mbalik, jauh."

Dengan terbatasnya waktu, anggaran, serta jumlah anggota tim yang harus memeriksa seluruh sampel kecamatan, tak jarang proses pemeriksaan dilakukan dengan $l d r$-an meminjam istilah anak muda sekarang. Ketua Tim harus memploting anggotanya berdasarkan jumlah penerima hibah, dan wilayah. Semisal ada 80 penerima hibah yang harus diperiksa dengan 2 anggota dan 10 hari pemeriksaan, maka satu hari seorang anggota tim harus memeriksa 4 titik. Bisa saja jarak antar penerimanya dekat jika beruntung. Namun bisa saja antar lokasi ini harus ditempuh dengan berjalan kaki karena medan yang tak mungkin dilalui dengan mobil (misal memeriksa fasilitas sumber air di puncak bukit), dan sering pula jarak antar lokasi (dari satu desa di kecamatan $x$ menuju desa di kecamatan y) harus ditempuh dalam hitungan jam. Keadaan ini dapat menguras tenaga pemeriksa. Tabu bagi pemeriksa untuk melewatkan satu penerima yang berlokasi di desa terpencil. Karena justru semakin terpencil dan tak terjangkau, disitulah biasanya penyelewengan terjadi. Dalam kasus Bapak Narto di sebuah SMK diatas, nampak bahwa peristiwa bersitegang sering dialami pemeriksa dengan penerima. Adanya dana 20 juta yang tidak dapat dipertanggungjawabkan, sempat dinego oleh penerima hibah namun akhirnya mau mengembalikan dan setor kas daerah. Namun demikian nampaknya cerita diatas berakhir happy ending bagi kedua belah pihak sebagaimana dikisahkan lebih lanjut oleh Bapak Narto, sembari menikmati chicken burger buah tangan peneliti

"Dua atau tiga bulan kemudian dia telp lagi. Bilang terima kasih, nggak jadi diperiksa polisi katanya. Karena sudah punya bukti setor waktu saya periksa."

Pemaknaan peran auditor internal yang dilaksanakan sebagaimana versi Bapak Narto diatas, meggambarkan bahwa satu-satunya cara mengamankan Bansos 
Hibah yaitu dengan mengembalikan kerugian. Setiap penerima dengan kondisi apapun wajib mengembalikan uang yang "tidak sesuai peruntukan" dan menyetorkan kepada kas daerah.

Senada dengan Bapak Narto, Bapak Danang yang diwawancarai di perpustakaan kantor pada sore hari menjelang jam pulang kantor, menyampaikan

"Kalo kita berperan sebagai konsultan di dalam masa pemeriksaan jika yang terjadi ketidaklengkapan pertanggung jawaban, justru disini kita mengajari bagaimana supaya lengkap sesuai dengan ketentuan. Tetapi tidak dengan substansinya. Ketika substansinya terjadi penyimpangan ya tetep. Yah ga ada kata lain. Penjaminan yang kita lakukan itu menghilangkan substansi nya ketika kegiatan 4 hari ternyata betul-betul dilak-sanakan 3 hari ya satu hari harus dikembalikan. Itu penjaminan. Harusnya begitu kalo lainnya ya gak ngerti tapi harusnya begitu."

Terdapat dua poin penting disini bahwa sebagai auditor, kewajiban sebagai konsultan harus dilaksanakan sebagaimana amanat Keputusan Nomor: KEP005/AAIPUDPN/2014 tentang Pemberlakuan Kode Etik Auditor Intern Pemerintah Indonesia, Standar Audit Intern Pemerintah Indonesia (SAIPI), dan Pedoman Telaah Sejawat Auditor Intern Pemerintah Indonesia Dewan Pengurus Nasional (DPN) Asosiasi Auditor Intern Pemerintah Indonesia (AAIPI) bahwa auditor intern harus berperan sebagai assurance, consultant dan giat dalam anti corruption activity. Seringkali penerima bansos hibah adalah masyarakat yang awam akan laporan pertanggungjawaban. Sehingga sebuah kewajiban untuk menjelaskan penyusunan laporan demi akuntabilitas pelaksanaan Bansos Hibah. Adapun pemaknaan Bapak Danang dalam menjaga pelaksanaan Bansos Hibah ini pun sama, yaitu pengembalian atas dana yang tidak sesuai dengan peruntukan. Ini adalah bentuk penjaminan, atau pelaksanaan fungsi assurance yang selama ini dilakukannya.

Namun demikian, pandangan yang berbeda disampaikan oleh Bapak Herman. Percakapan dilakukan di kantor beliau, sembari sesekali menandatangani dokumen yang diajukan pada beliau. Volume pembicaraan kami sangatlah lirih, karena model ruangan kantor kubikal yang terbuka berbagi dengan staf beliau dan topik pembicaraan kami yang lumayan "sensitif" yaitu tentang Bansos Hibah. Bapak Herman telah memeriksa sejak Tahun 1995. Namun demikian setahun terakhir telah berpindah tugas pada SKPD pelaksana/pemberi hibah. Sedikit banyak bekalnya dalam melakukan pemeriksaan membantu tugas beliau agar dapat menyalurkan bantuan sesuai ketentuan yang ada. Beliau mengisahkan beberapa pengalamannya sewaktu memeriksa dahulu

"Harus teges. Kita itu dulu banyak temuan, jelas geger karena dulu kita sampe nulis dari komisi apa fraksi apa. Akhire kita nggak boleh nulis itu. Kono nyerah malah kene kon mbenerne SPJ. Berubah fungsi dadi pendamping. Kan kudune dadi konsultan. Tapi konsultan nek enek sing bengkok diluruske. Dudu pembenar wes golek no iki ae..goleko bukti iki. Kudune sing bener yo volumene fisike tambahono SPJ ne tambahono. iku sing bener. Harusnya kita begitu. Gak kok ndi golekno foto sing apik dadekno foto... iku pembenar."

Pernyataan ini menyiratkan bahwa ketika beliau melakukan pemeriksaan pada sebuah pokmas dengan memberikan laporan yang rigid bahkan hingga menuliskan nama aspirator (pihak legislatif), menjadi sebuah benturan kepentingan. Dan 
laporannya tersebut terpaksa diperbaiki, dengan perintah pengirim peran pada saat itu untuk melakukan "pendampingan". Pendampingan dalam hal ini, membantu menyusun SPJ agar rapi sesuai proposal yang diajukan. Namun demikian, tanpa dibarengi dengan pemenuhan kekurangan bangunan fisik di lapangan. Peran inilah yang tidak semestinya dilakukan oleh auditor internal, namun demikian "terpaksa" dilakukan. Dengan kata lain justru form over substance.

"Iki biyen enek seorang pengurus tempat ibadah, Bangunane senilai 5 milyar kirokiro. Njaluk bantuan hibah rehab dikei 200juta. Untuk apa proposalnya untuk lantai, tempat membasuh..nah pemeriksaan kan setaun kemudian. Bapak kui mau takon lapo katek diprikso barang.. Pak Gubernur ga ikhlas ta ngekei..Lah.. Bukan ikhlas ga ikhlase... pertanggungjawaban..haha.. Pak Gubernur bagemanna kok minta macem-macem, apa nggak ikhlas.. ini.. (menirukan dengan logat xxx) Wah repot iki..Bukan begitu Pak inikan Pak Gubernur juga sebagai pengelola keuangan ditanyai oleh BPK....nah ini ganti meriksa. Termasuk disini juga menerima..Duitnya apa sudah diterima, sesuai proposal. Dimana buktinya. Diduduhno bangunane tok.. sing endi.. Padahal tempat membasuh wis lawas.. Yowes dilep (dimakan) ngono tok ae (bantuannya).

Seperti yang disampaikan di awal tulisan, bersitegang dengan penerima bantuan kerap terjadi. Tak jarang para auditor internal ditakuti dengan senjata tajam. Terkadang difoto plat mobilnya, difoto orangnya untuk dilaporkan pada "atasan" penerima bantuan. Posisi inilah yang kadang membuat dilema bagi auditor internal. Dimana harus memilih menulis fraud ataukah menerima perintah untuk menjadi "pendamping" tadi. Bapak Herman melanjutkan penjelasannya

"Lha aku mau lak ngomong, kalo dibuat temuan...geger.. Akhirnya trus mbalik ngono lo dadi pendamping. Akhire trus ngajari nggae SPJ..yo ndikte.. Biyen awakmu njanjeni opo.. Oh itu pak mbenerkan kran nya pipa.. Fotone endi..tuku alate pasir watu ... Wes yokui maeng mau jadi pembenar atau jadi eksekusi. Eksekusi kebenaran lo bukan eksekusi kesalahan. [...] Sing bener sing ndi..Ya memang harus komitmen bersama. Kudune yoo bener Pak Jokowi itu Revolusi Mental. Seharusnya hibah bansos itu komitmennya yang harus kuat.Saiki yo ngesakno nek ada orang bener-bener butuh bansos..disalahagunakan oknumoknum."

Peran pendamping atau pembenar sebagaimana diungkap oleh Bapak Herman, riil pernah terjadi dalam pemeriksaan. Padahal peran ini bukan merupakan peran yang "diamanatkan" oleh peraturan bahwa auditor internal merupakan Pengawas Penyelenggaraan Pemerintah sebagaimana tercantum pada PP No 18 Tahun 2016 tentang Perangkat Daerah. Peran ini adalah peran yang "diharapkan" oleh pengirim peran. Pun demikian hal ini terjadi karena conflict of interest atau benturan kepentingan antara pihak eksekutif dengan pihak legislatif. Hal ini merupakan contoh episode dilema yang dialami para auditor. Jika tidak mengindahkan perintah tersebut, bisa saja hal ini akan berpengaruh pada komunikasi lanjutan dan penugasan berikutnya. 


\section{Pemeriksaan pada Penerima Bantuan Sosial Perorangan dan Pokmas.}

Lain halnya dengan pengalaman Bapak Jarwo. Kisahnya dalam memeriksa penerima bantuan sosial telah digambarkan di paling awal tulisan. Sore itu selepas pulang dari kantornya, Informan bersedia mengupas tuntas pengalamannya dalam melakukan pemeriksaan Bansos dan Hibah dan memutuskan untuk mengadakan wawancara di rumah makan berkonsep lesehan. Dengan memesan Avocado Juice dan Gurame Bakar percakapan berlangsung sersan. Serius tapi santai. Bapak Jarwo yang telah menjadi pemeriksa sejak Tahun 1999 mengisahkan dimana disaat memeriksa bantuan sosial berupa ternak, kambing yang diterima tak lama dijual pada tengkulak dan menjadi cincin. Padahal niatan pemerintah memberi Bantuan Sosial ternak adalah agar kambing tersebut tumbuh besar, beranak, berkembang biak dan terus bergulir dan dapat dibagikan kepada saudara lainnya. Tentu saja dalam kasus seperti ini, Bapak Jarwo tidak dapat serta merta menyalahkan nenek tersebut. Keadaan nenek yang sebatang kara ini tidak memungkinkan untuk memelihara hewan ternak. Dalam kasus ini, proses verifikasi yang dilaksanakan oleh sebuah biro pelaksana pemberi bantuan sosial kurang tepat. Boleh saja seorang nenek yang kurang mampu mendapat bantuan hewan ternak jika masih memiliki anak atau kerabat yang dapat membantu angon wedhus. Menanggapi kasus ini, Bapak Jarwo memberi rekomendasi dan teguran kepada pelaksana survey yang kurang selektif dalam memberikan bantuan. Bantuan benar tersalurkan namun menjadi tidak tepat dan kurang bermanfaat jangka panjang. Pemeriksaan Bansos Hibah bersifat post audit. Sehingga tidak dapat mengawal pada saat perencanaan. Masih diceritakan Bapak Jarwo dirinya pernah menemui pekerjaan yang belum dilaksanakan sama sekali hingga waktu pemeriksaan dilaksanakan.

"Kalo nulis temuan harus ngasih solusi. Misale wayahe sepatu item kok nggae sepatu putih, Ojo disalahkan tok.. Tanya dulu. Kalo Gak punya pak yowes tak silihi..Jadi temuan tulis disik tapi gak marah ga kroso kalo tak tulis. Kalau bansos hibah, misalnya tak kasih waktu misal dee gurung garap Mateng yo..sampean ambek polisi iki pak nek ngene eruh iki. Wes gini ae wes, misal sampean mbangun gazebo iki piro sih butuh waktune seminggu dadi? Padahal aku due spare 2 minggu. Lek ga dadi yok opo sampean resikone aku gak melu opo-opo loya. Dadi pak! Jare. Lek ngono gae pernyataan. Lek ga dadi seminggu nek polisi teko aku ga melok opo-opo loyo. Penyataan iki tak kekno polisine. Asline sampean iki wes kenek aku cuma nulungi sampean. Aku gak mau tau uangnya mbangun darimana. Mboh nyilih ta opo. Uangnya dah habis kali ya yang dulu dah dihabiskan. Pokoknya jadi. Seminggu difoto di wa. Dia lapor, Pak jadi. Yowes, Jangan gitu aja ayo SPJnya dilaporkan. Itu teniknya harus ngasih solusi."

Nampak dengan jelas bahwa Bapak Jarwo mengedepankan solusi bersama, tidak hanya menyalahkan namun memberi waktu agar bangunan yang dimintakan bantuan benar-benar dibangun dan bermanfaat nantinya. Menurut pak Jarwo, bisa saja dia meminta agar uang dikembalikan ke kas daerah karena hingga waktu pemeriksaan belum dilaksanakan sama sekali. Namun demikian kelak masyarakat yang memerlukan fasilitas tersebut, harus mengurus kembali prosedur dari awal yaitu pengajuan proposal. Meski dengan sedikit ancaman dan membawa nama aparat penegak hukum (polisi), penerima hibah menyetujui pelaksanaan pembangunan 
gazebo yang diperlukan masyarakat sebagai fasilitas pada budidaya ikan dan menyelesaikannya sesuai pernyataan yang ditulis sewaktu diperiksa Bapak Jarwo.

\section{Pemeriksaan pada Penerima Hibah Lembaga Pemerintah}

Selama seminggu, peneliti melakukan observasi partisipatif, bergabung dengan tim pemeriksaan hibah pada penerima lembaga K. Terdengar suara senandung Pengendali Teknis (Dalnis) Tim Auditor sambil menginput dokumen SPJ kedalam kolom excell di laptopnya. Jarang sekali dalam pemeriksaan Dalnis ikut turun langsung menginput data. Namun untuk tugas kali ini sangatlah berat, sehingga sebuah kewajiban untuk ikut serta melakukan rekapitulasi dan tidak hanya membagi tugas dan mengevaluasi hasil pemeriksaan. Sudah dua hari berlalu tim menginput secara manual dokumen demi dokumen SPJ yang jumlahnya sekitar 30 an (ya benar tiga puluh lebih) box plastik besar beroda dengan tutup dan berpengait pinggir. Hal ini dikarenakan bendahara pengeluaran pada Tahun Pemeriksaan kasus berkaitan tidak menyusun Buku Kas Umum (BKU). Padahal ini adalah catatan penting dan mendasar setiap bendahara. Perkumpulan ibu-ibu kampung saja tertib dalam pencatatan. Namun entahlah, bendahara ini membuat pernyataan bahwa dia tidak menyusun BKU.

Nampak anggota tim lain yang kebetulan sedang hamil menggaruk perutnya sembari memeriksa bukti cek transfer ke Kabupaten Kota. Sesekali anggota tim lain menginput sambil bercerita tentang anaknya dan topik ringan lain serta berdiskusi tentang Pph. Tim terdiri dari Pengendali Teknis, Ketua Tim dan tiga anggota. Ibarat makanan, ini adalah tim paket hemat saja, padahal harus memeriksa dana hibah puluhan miliar namun hanya menurunkan 5 personil dengan waktu efektif satu minggu. Suara tuts keyboard laptop terdengar tuk tuk tuk tuk cepat. Semakin siang, suasana makin panas karena mesin pendingin dalam ruangan yang biasa digunakan untuk konferensi pers tidak berfungsi dengan baik. Mengingat tidak adanya BKU untuk mencatat nilai pengeluaran kasnya, maka langkah pemeriksaan yang dilakukan adalah dengan membuat rekapitulasi pengeluaran kas berdasarkan bukti pertanggungjawaban yang disampaikan kepada Tim Pemeriksa.

Rekapitulasi pengeluaran kas yang dibuat oleh Tim Pemeriksa dibuat untuk dapat dibandingkan kesesuaian jumlahnya dengan nilai realisasi belanja yang tercantum dalam rekapitulasi pertanggungjawaban belanja hibah yang telah dilaporkan sebelumnya kepada instansi yang berwenang. Ratusan bendel dokumen diperiksa secara manual dan diinput uraian belanja serta nilai pajak dan realisasi pengeluaran beserta keterangan temuan tiap dokumen, semisal dokumen tidak ditandatangani, tidak ada SSP, tidak ada pungutan pajak dan sebagainya. Betapa melelahkan menginput manual puluhan milyar belanja ini. Apalagi ditambah mereka harus mengenakan masker karena dokumen-dokumen tiga tahun yang lalu yang sangat berdebu. Bahkan salah satu anggota tim merasa dia "dikerjai" oleh pemberi tugas karena harus mengerjakan tugas yang sangat berat ini. Konfirmasi terhadap pejabat yang menangani kala itu juga terbatas karena beberapa telah masuk penjara akibat menggelapkan pajak. Namun demikian, tugas ini dapat diselesaikan dengan baik oleh tim tersebut dengan hasil terdapat selisih realisasi belanja, adanya pajak yang belum disetor dan beberapa temuan penting lainnya. Terhadap hal ini Bapak Laksono Penanggungjawab Tim memberikan pernyataan 
"Pokoe selisih berapapun harus diganti oleh pengurus lama. Piro tetep ta kon nggenti. Tapi tetep mlebu dee.. masuk.. (penjara). Bagaimana kalo tidak dibuat BKU.. Yo sing jelas iku kesalahan absolut dalam peraturan. Teknis auditnya yo dibalik, diperiksa dari bukti dokumen."

Peran mengamankan uang negara sebesar puluhan milyar ini pun sempat diwarnai percobaan gratifikasi. Namun demikian map kertas berisi "sesuatu" yang tebal sehingga map kertas nampak kaku tidak dapat dilipat tersebut ditolak dengan halus oleh Ketua Tim. Etika pemeriksaan tetap harus dijaga terlebih saat menangani kasus yang rumit dan krusial, pasti ada godaan.

Namun demikian, berbeda dengan Bapak Narto sebagaimana disampaikan berikut:

"Ketika ada masalah itu pertama kita seringkali menghindar, jadi di awal kan memang dihindari di awal. Dihindari dengan alasan apapun. Karena resiko pekerjaannya nggak sebanding Kalau aku pribadi sih kuhindarin. Mana aku pernah masuk bansos hibah "K"? nggak pernah. Kan itu Surat Perintah Tugas (SPT) khusus, bukan bansos hibah yang reguler. Kalau SPT khusus...Ndak mau. Bukan ndak mau, wedi... hehe... aku wedi. Karena pasti ada .., aku wegah, wedi aku."

Bapak Narto mengungkapkan keengganannya jika diminta untuk menjadi tim dalam pemeriksaan hibah pada lembaga yang menerima dana yang tidak sedikit. Hal ini menurutnya karena pasti ada amanat khusus dari pengirim peran. Menurut pendapatnya, lebih baik dia menolak penugasan tersebut dan tidak masalah jika hal ini akan berakibat pada penugasan berikutnya. Baginya lebih baik melakukan pemeriksaan pada penerima kelompok masyarakat, atau perorangan ataupun pada lembaga yang tidak terlalu berisiko. Penghindaran ini adalah keputusannya semata daripada harus dilema melaksanakan tugas sesuai dengan harapan pengirim peran.

\section{Tindak Lanjut Pemeriksaan Bansos Hibah}

Apalah arti pemeriksaan jika hasilnya tidak ditindaklanjuti. Sesuai Peraturan MenPAN RB 9/2009, bahwa pemeriksaan oleh pemeriksa internal harus ditindaklanjuti selambatnya 90 hari sejak LHP diterima. Tindak Lanjut merupakan eksekusi dari apa yang ditulis oleh auditor dalam Laporan Hasil Pemeriksaan. Dalam menindaklanjuti temuan bansos hibah menjadi susah-susah gampang karena penerima bansos hibah memiliki latar belakang SDM yang beragam. Sebagaimana dituturkan oleh Ibu Shinta: "SPJ sudah rapi, tapi fisik di lapangan masih...gitu tidak sesuai realisasi SPJ."

Dari pernyataan Ibu Shinta ini sedikit memberikan gambaran bahwa memang benar adanya form over substance di lapangan, dimana laporan yang rapi, namun tidak sesuai dengan apa yang ada di lapangan. Tentunya terhadap hal seperti ini menjadikan apa yang dilakukan oleh auditor internal mdalam melakukan pemeriksaan menjadi sia-sia jika tindaklanjut tidak dilakukan dengan maksimal. Dan besar kemungkinan hal ini akan menjadikan temuan yang berulang kedepannya. 


\section{SIMPULAN}

Penelitian ini bertujuan untuk menggali realitas peran auditor internal pemerintah dalam Bansos Hibah. Peran yang seharusnya dijalankan oleh auditor internal sesuai dengan amanat perundangan adalah sebagai pengawas, assurance, consultant dan anti corruption activity. Namun demikian, dalam pelaksanaan riil di lapangan, terdapat beberapa pelaksanaan peran yang tidak sesuai dengan peran yang diharapkan. Temuan dalam penelitian ini sesuai dengan Teori Peran Katz dan Kahn (1978). Dalam teori peran, peran dianggap sebagai konsep jamak dengan serangkaian jajaran peran yaitu harapan peran, peran yang dikirim, peran yang diterima dan perilaku peran yang dikenal sebagai role set. Teori ini dapat dipakai untuk menarik beberapa konklusi tentang berbagai peran yang dilaksanakan oleh sang penerima peran dalam hal ini auditor internal pemerintah (inspektorat). Dan realitas di lapangan sesuai dengan teori ini yaitu harapan yang sering berbeda dengan peran yang dikirim, dan antara peran yang diterima memiliki banyak versi pelaksanaan peran. Atau jika digambarkan dalam sebuah ilustrasi mengacu pada teori peran, maka hasil penelitian tergambar sebagai berikut:

Gambar 1. Peran auditor dalam bansos hibah

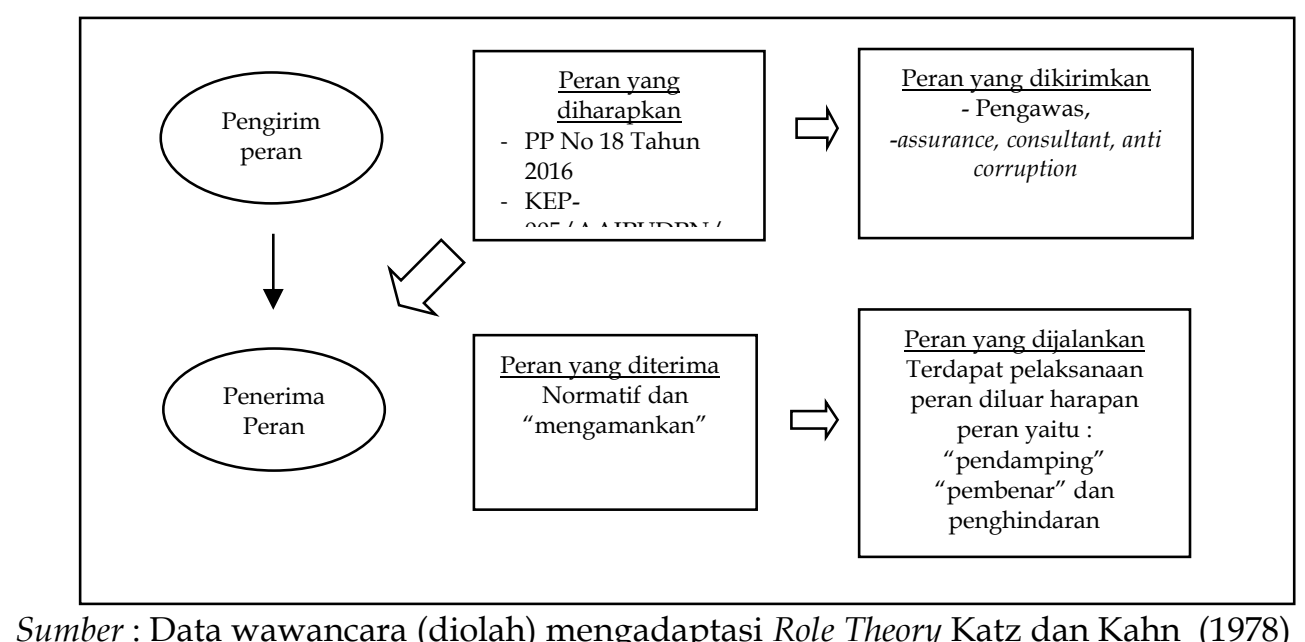

Permasalahan dalam bansos hibah sangatlah kompleks. Bukan berarti auditor internal tidak dapat melaksanakan tugasnya, meski terdapat beberapa pelaksanaan peran diluar peran yang diharapkan. Diperlukan komitmen yang kuat dan integritas yang tinggi dari semua pihak, agar korupsi dalam bansos hibah tidak menjadi kasus yang mendominasi dalam catatan penyelenggaraan pemerintahan daerah. Terakhir penulis menukil apa yang pernah diucapkan Busyro Muqoddas Ketua KPK ke-3 : "Pemberantasan korupsi di Indonesia harus diletakkan dalam konteks pembebasan rakyat yang tertindas. Penindasnya adalah proses politik yang korup dan tak menjadikan rakyat berdaulat di negerinya." Semoga dapat menjadi perenungan bersama. 


\section{DAFTAR PUSTAKA}

Achyani, E. 2014. Analisis Efektivitas Pelaksanaan Belanja Batuan Sosial Di Kabupaten Pontianak Tahun 2009 - 2013. Tesis. Universitas Gadjah Mada, Yogyakarta.

Adil, S., dan M. Anwar. 2015. Impact of Financial Decentration on Economic Growth: The Case of Pakistan. Pakistan Journal of Social Sciences, 35

Akai, N., dan M. Sakata. 2002. Fiscal Decentralization Contributes to Economic Growth: Evidence Form State-Level Cross-Section Data for the United States. Journal of Urban Economics, 52, 93-108.

Chempaka. 2015. Analisa Peran Auditor Internal Pemerintah Dengan Teori Peran. Tesis, Universitas Airlangga, Surabaya.

Darmastuti, D., dan D. Setyaningrum. 2012. Faktor-Faktor Yang Mempengaruhi Pengungkapan Belanja Bantuan Sosial Pada Laporan Keuangan Pemerintah Daerah Pada Tahun 2009. Universitas Indonesia, Jakarta.

Delli, H. 2014. Peranan Spip Dalam Mengelola Belanja Bantuan Sosial (Studi Kasus Pada Pemerintah Daerah Kabupaten Aceh Tengah). Tesis. Universitas Gadjah Mada, Yogyakarta.

Eftriani, Z. 2014. Proses Perumusan Anggaran Belanja Hibah Dan Bantuan Sosial Apbd Provinsi Kepulauan Bangka Belitung

Gamar, N., dan A. Djamhuri. 2014. Auditor Internal Sebagai "Dokter" Fraud Di Pemerintah Daerah. Jurnal Akuntansi Multiparadigma JAMAL, 6.

Katz, D., dan R. L. Kahn. 1978. The Social Psychology of Organization: John Wiley \& Sons.

Lintartika, G. (2015, 4 April 2016). Urutan Kedua Terbanyak Gizi Buruk. Harian Surya, p. 1.

Mandasari, M., N. A. S. Darmawan, dan A. T. Atmadja. 2015. Akuntabilitas Pengelolaan Keuangan Dana Bansos Pada Majelis Ta'lim Muslimat $\mathrm{Nu}$ Ukhuwah Islamiyah Kampung Anyar, Singaraja, Bali. Jurnal Akuntansi Ganesha, 3.

Manossoh, H. 2015. Studi Fraud: Implementasi Kebijakan Pengelolaan Belanja Hibah Dan Bantuan Sosial Pada Pemerintah Kota Manado. Airlangga, Surabaya.

Mardiasmo, D., dan A. MBA. 2002. Akuntansi Sektor Publik. Andi Yogyakarta, Januari.

Rahmawati, N. 2016. Studi Penetapan Dan Pengelolaan Dana Bansos Hibah Di Surakarta. Universitas Muhammadiyah Surakarta, Surakarta.

Roussy, M. 1. 2013. Internal Auditors' Roles: From Watchdogs to Helpers and Protectors of the Top Manager. Critical Perspectives on Accounting, 24.

Santoso, J. 2016. Dinamika Pemikiran Makna Efektiitas Peran Aparat Pengawas Internal Pemerintah. Tesis. Universitas Airlangga, Surabaya.

Shariha, J. 2014. The Role of Audit Bureau in Eradicating Financial Corruption in Libya. Jurnal Akuntansi Multiparadigma JAMAL, 5. 
Syafingi, H. M. 2014. Aspek Korupsi Dalam Belanja Hibah Bersumber Pada Anggaran Pendapatan Dan Belanja Daerah. Universitas Muhamadiyah Magelang.

Widada. 2015. Analisis Belanja Hibah, Belanja Bantuan Sosial, Belanja Bantuan Keuangan, Dan Belanja Modal Selama Dua Periode Kepemimpinan Kepala Daerah Di Pulau Jawa, 2000 - 2014. Tesis, Universitas Gadjah Mada.

Widati, F. M. 2016. Evaluasi Pelaksanaan Audit Investigatif Pada Inspektorat Daerah Kabupaten Kulon Progo. Universitas Gajah Mada, Yogyakarta.

Yin, R. K. 2013. Case Study Research: Design and Methods: Sage publications. 